Ющенко Наталія Вікторівна аспірант кафедри державного управління, публічного адміністрування та регіональної економіки Харківського національного економічного університету імені Семена Кузнеця, проспект Науки, 9А, Харків, Харківська область, 61000, тел.: (057) 702-18-34, e-mail: nataliya.yushchenko@hneu.net, https://orcid.org/0000-0002-3396-8013

Базько Олександра Андріївна здобувач Науково-дослідного центру індустріальних проблем розвитку НАН України, Інженерний провулок, 1-a, Харків, Харківська область, 61000, тел.: (050) 622-61-48, e-mail: a.a.bazko@gmail.com, https://orcid.org/0000-0003-1809-4917

\title{
ОСОБЛИВОСТІ ТРАНСФОРМАЦІЇ ЕЛЕКТРОННОГО УПРАВЛІННЯ В СУЧАСНОМУ СУСПІЛЬСТВІ
}

Анотація. Останні роки велика увага приділяється розвитку електронного урядування в країні. Розробляються нові електронні послуги, системи ідентифікації, нові платформи. В перше чергу електронне урядування дає змогу вдосконалювати адміністративні процеси, впорядковувати організаційний механізм публічного управління. Але досі немає чіткої взаємодії органів державної влади та місцевого самоврядування як по горизонталі так і по вертикалі. У світі відбувається трансформація урядування від електронного до цифрового та акцентується увага на користувачах послуг: громадянах, бізнес-структурах та громадських організаціях. Публічне управління стає все більш клієнтоорієнтованим. Відбувається зміщення центру уваги від інформатизації публічного управління до розвитку концепції інтелектуального управління. Визначено, що Україна в сфері розвитку електронного урядування на місцях займає не високі позиції і потребує дієвих механізмів розвитку регіонів. Ретельної уваги потребує запровадження цифрових трансформацій в містах. Від оцінки технічних можливостей та IКТ інфраструктури до зручності та комфортності надання електронних послуг. Високої ефективності цифрових перетворень можливо досягти після розбудови детальної стратегії розвитку електронного міста, регіону з чітким визначенням механізму взаємодії усіх гілок влади. Розвиток інформаційного суспільства $€$ пріоритетним напрямком розвитку країни в цілому, та в відповідності до європейських стандартів вимагає впровадження сервісно-орієнтованої державної політики. Тому вкрай важливо мати чітку стратегію розвитку країни в цілому, яка враховує особливості розвитку регіонів. Побудова стратегії впровадження електронного урядування та цифрового розвитку країни повинна починатися 3 оцінки ресурсів, які $є$ в наявності, стикуватися 3 можливостями і напрямками розвитку регіонів та навпаки, розвиток регіонів повинен чітко інтегруватися в стратегію розвитку країни в цілому. 
Ключові слова: електронне урядування, цифрове урядування, електронний регіон, електронне місто, публічне управління.

Yushchenko Nataliya Viktorivna PhD student of Public Administration and Regional Economy Department, Simon Kuznets Kharkiv National University of Economics, Nauki Avenue, 9A, Kharkiv, Kharkiv region, 61000, tel.: (057) 702-18-34, e-mail: nataliya.yushchenko@hneu.net, https://orcid.org/0000-0002-3396-8013

Bazko Oleksandra Andriivna applicant of the Research Center for Industrial Development Problems of the National Academy of Sciences of Ukraine, Engineering Lane, 1-a, Kharkiv, Kharkiv region, 61000 tel.: (050) 622-61-48, e-mail: a.a.bazko@gmail.com, https://orcid.org/0000-0003-1809-4917

\section{FEATURES OF E-GOVERNANCE TRANSFORMATION IN MODERN SOCIETY}

Abstract. In recent years, much attention has been paid to the development of egovernment in the country. New electronic services, identification systems, new platforms are being developed. First of all, e-government makes it possible to improve administrative processes, streamline the organizational mechanism of public administration. But there is still no clear interaction between public authorities and local self-government both horizontally and vertically. The world is transforming government from electronic to digital and focuses on service users: citizens, businesses and NGOs. Public administration is becoming more customer-oriented. There is a shift in the focus from the informatization of public administration to the development of the concept of intellectual management. It is determined that Ukraine does not occupy high positions in the field of e-government development on the ground and needs effective mechanisms for regional development. The introduction of digital transformations in cities needs careful attention. From the assessment of technical capabilities and ICT infrastructure to the convenience and comfort of providing electronic services. High efficiency of digital transformations can be achieved after the development of a detailed strategy for the development of the electronic city, the region with a clear definition of the mechanism of interaction of all branches of government. The development of the information society is a priority for the development of the country as a whole, and in accordance with European standards requires the implementation of service-oriented public policy. Therefore, it is extremely important to have a clear strategy for the development of the country as a whole, which takes into account the peculiarities of regional development. Building a strategy for the implementation of e-government and digital development of the country should begin with an assessment of available resources, match the opportunities and directions of regional development and vice versa, regional development should be clearly integrated into the development strategy of the country as a whole.

Keywords: e-government, digital government, e-region, e-city, public administration. 
Постановка проблеми. Швидкий розвиток цифрових технологій, інновації у сфері управління, трансформація державного управління зумовили хід динамічних процесів, які змінюють соціальні, економічні, державні відносини та потребують ретельної уваги та адекватних рішень. Тому електронне урядування стає одним 3 головних інструментів у побудові прозорого, ефективного та гнучкого публічного управління. Широкі можливості інформаційнокомунікаційних технологій дають можливість побудувати ефективну систему публічного управління, зорієнтовану на потреби суспільства та що трансформуються за участю громадян. Все це робить тему даного дослідження актуальним та своєчасним.

Розглядаючи структуру механізму електронного урядування важливо усвідомлювати дві його складові: зовнішню ті внутрішню. Зовнішня складова відповідає за взаємодію влади та суспільства, включаючи в себе взаємодію 3 громадянами, бізнесовими структурами та некомерційними організаціями. Внутрішня складова відповідає за автоматизацію та трансформацію взаємодії на різних рівнях влади, як центральної, регіональної та місцевої, так і виконавчої, законодавчої та судової [1].

Аналіз останніх досліджень i публікацій. Дослідженням проблем впровадження електронного урядування в Україні присвячені труди багатьох вчених, таких як, Г. Атаманчук, О.Баранова, С. Барегамян, М.Вершинін, Т.Запорожець, П.Клімушин, О.Орлов, А. Семенченко та багатьох інших.

Мета статті - дослідження основних напрямів розвитку складових електронного урядування в органах публічної влади на державному рівні країні та iii регіонів.

Виклад основного матеріалу. Стрімкий розвиток цифрових технологій ставить нові вимоги до розбудови електронного урядування. На сьогоднішній день це не лише ефективне управління за допомогою ІКТ, цифрові навички та доступ до інтернету. На думку Запорожець Т. відбувається трансформація моделі «електронного урядування» до моделі «уряд як платформа». Перехід до моделі «уряд як платформа», або дата-центрічний уряд відбувається за рахунок використання інтелектуальних технологій та спільного використання програмних продуктів та даних. При такому підході уряд розглядається як механізм, який сприяє діяльності в публічній сфері, а не як постачальник послуг. Наступним кроком є формування «цифрового урядування», яке $\epsilon$ основою запровадження інтелектуального управління. В більш розвинених країнах уряди зосереджуються на наданні клієнто-центричних послуг, де в центрі уваги знаходяться користувачі. Аналіз поведінки та потреб користувача у минулому, аналітика даних дають змогу робити прогноз о негайних потребах [2].

Побудувати та оптимізувати горизонтальний та вертикальний зв'язок органів влади в України намагається за допомогою фахівців з «цифрової трансформації». Для розбудови ефективного електронного урядування потрібно результативне горизонтальне співробітництво та координація публічних установ на національному та місцевому рівні. Це вимагає крім технічної інфраструктури активного бажання керівництва та службовців державного сектора, високої культури та відповідальність, бо низька цифрова обізнаність та бюрократичні 
звички гальмують трансформаційні процеси, без них неможливий ефективний реінжиніринг адміністративних процесів.

На сьогоднішній день уряд активно займається трансформацією процесів урядування, прямуючи до цифрового світу та акцентуючи увагу на основних проблемних аспектах. Згідно з дослідженнями ООН 2020 року Україна поліпшила свій рейтинг та посіла 69 місце у рейтингу розвитку електронного уряду маючи індекс 0,7119 проти 82 місця з індексом 0 ,6165 у 2018 року. Найбільший проріст має під індекс ТІІ (телекомунікаційної інфраструктури) - 0,15 пунктів, під індекс OSI (онлайн послуг)- на 0,11 , а під індекс НСI (людський капітал) - збільшився лише на $0,01$.

За рейтингом Електронної участі Україна посіла 46 місце з показником - 0 ,80 95 значно покращивши свої позиції.

Індекс розвитку відкритого уряду (Open Government Data Index - OGDI) $\epsilon$ похідним в якості додаткового індексу до онлайнового Індекс обслуговування (OSI). Він розширює масштаб дослідження, зосередившись на використанні відкритого уряду даних (OGD). OGDI визначає три ключові вимірювання у своїй поточній структурі, які є: політичні та інституційні рамки (як основа); платформа (наявність порталу OGD і його функцій); доступність даних у різних секторах, таких як охорона здоров'я, освіта, зайнятість, соціальне забезпечення, навколишнє середовище i правосуддя) i застосування даних (наприклад, шляхом організації хакатонів). Цього року Україна має показник індексу - 0 ,8969 [3]. Але OGDI індекс враховує лише наявність та доступність відкритих даних. Ефективне електронне урядування має на увазі зростання відкритості уряду, а за показниками Індексу відкритості уряду (WJP Open Government Index 2020 ) Україна практично не змінює свої позиції та займає 72 місце демонструючи низькі позиції в відсутності корупції та правосуддя [4].

Розвиток електронного урядування та інформаційних технологій країни світу відслідковують по багатьом індексам і рейтингам. Але значний інтерес представляє розвиток електронного урядування в містах. ООН у 2018 році запровадила індекс розвитку локального онлайн обслуговування та склала рейтинг для 40 найбільших муніципалітетів світу. У 2020 році географія оцінки була розширена до 100 муніципалітетів. Київ зайняв у рейтингу 50 місце 3 невисоким індексом 0,35 , лідером виявився Мадрид маючи показник LOSI - 0,9625.

Оцінка локального онлайн обслуговування складається 380 показників, які формують 4 групи: технології, представлення контенту, сервісні послуги, участь та залучення. У технологічній групі оцінюється браузерна сумісність та простота навігації, наявність механізм пошуку, узгодження зі стандартами доступності та валідності, доступність декількох мов. Представлення контенту оцінюється за наявності інформації о місті та міської влади: контактної, організаційної структури, відкритих закупівель та бюджеті міста. Крім того розглядається наявність стратегії цифрового уряду та інформація о послугах, що надаються, інформація про освіту, соціальне забезпечення, про дозвілля, культуру та спорт та інших сфер життєдіяльності. Але особлива увага приділяється ініціативам розумних міст та новітнім технологіям, онлайн підтримці користувачів та наданню статистичних даних та досліджень. Третя група показників - це онлайн послуги. Їх кількість та 
доступність, варіанти авторизації та гостьовий доступ, швидкість та якість відповіді на електронні запити, наявність чат ботів. Участь та залучення оцінюються за наявністю інструментів для електронних консультацій, збір громадської думки та можливості електронного голосування.

Вказаний рейтинг дає змогу оцінити зусилля, які докладають міська влада до розвитку ефективного цифрового міста, та виділити основні орієнтири для трансформації підходів до організації взаємодії з громадянами.

Найбільш показовими є цифрові взаємодії на регіональному рівні. В повсякденному житті громадяни частіше і ближче контактують 3 регіональними органами влади та місцевого самоврядування. Органи місцевого самоврядування мають більш повне поняття о колі проблем, які цікавлять громадян та місцевий бізнес, та відповідно, мають можливість швидше реагувати на їх потреби. Громадяни більш зацікавлені усім тим, що впливає на повсякденне життя, займаючи активну позицію у життедіяльності міста чи регіону мають змогу побачити результати такої взаємодії.

Розвиток електронного урядування на містах стикається з низкою проблем: 3 одного боку доступ до інтернету в маленьких містах та селах, 3 іншого боку відсутність цифрових навичок та довіри до електронних технологій у громадян. Згідно 3 дослідження Міністерства цифрової трансформації підключення населених пунктів України до волоконно-оптичних мережам становить лише 37,69 \% [5]. По областях ситуація виглядає ще критичніше від покриття Чернігівської області - 15,30 \% до Чернівецької - 84,37 \%. Нерозвинута інфраструктура IКТ, відсутність електронного взаємозв'язку між департаментами міста та регіону стає одним із чинників розвитку цифрової трансформації. Існуючі в світі інноваційні підходи для забезпечення ефективного розвитку міста та регіону потребують стабільної надійної інфраструктури, як апаратної так i програмної, здатної обробляти та аналізувати великі масиви даних. Але новітні технології потребують великих витрат, тому набуває актуальності залучення приватного бізнесу для реалізації проектів розвитку.

Ключовим фактором успішного впровадження електронної взаємодії є безпека даних, як приватних, так і державних. Забезпечення безпеки включає в себе як нормативно-правове, так і впровадження інструментів безпеки та конфіденційності. Кількість кібератак зростає 3 кожним днем, але досвід світової пандемії свідчить, про великий пріоритет цифрових технологій, як в управлінні, так і в повсякденному житті. Тому головна задача уряду побудувати захищене, гнучке, ефективне цифрове середовище в країні.

Існують похибки у запровадженні цифрових технологій, які розвиваються 3 неймовірною швидкістю та потребують фундаментального підходу до застосування. 3 одного боку, міста підключаються до програми Sma1tity розвивають електронні сервіси міської інфраструктури, концепції розумного міста, 3 іншого боку великі комунальні підприємства недостатньо змінюються, маючи мінімальні інструменти взаємодії 3 громадянами та бізнес структурами. Впровадження онлайн послуг та електронної взаємодії здатне знизити транзакційні витрати та спрощує бюрократичну складову, підвищує ефективність управління за рахунок скорочення помилок та часу, витраченого на повторювані операції. 
Електронне урядування, - це лише інструмент трансформації публічного адміністрування, головний орієнтир якого - люди. На думку деяких фахівців державні послуги повинні стати проактивними, а державні службовці невидимими [6]. Цифрові технології допомагають зрозуміти пріоритети населення чи бізнесу, сфокусувати проблеми та знаходити рішення для їх вирішення. Так, як цифровізація потребує сильного загального керування та відповідних інвестицій політичного, адміністративного, соціального та фінансового капіталів та повинні бути перетворені у специфічні стратегії, ініціативи та плани [7]. Тому потрібно чітко усвідомлювати, що портали державного чи регіонального рівня мають бути інтегровані у внутрішні процеси організації.

Механізм впровадження електронного урядування на регіональному рівні повинен розвиватися на основі детальної стратегії, яка має чітку ціль та ресурси для досягнення: інформація (документи в електронної формі, дані), процедури (нормативні акти, адміністративні регламенти), людські (керівники, виконавці, розробники, користувачі), технічне обладнання (комп'ютери, сеті, програмне ПО). Бачення цифрового розвитку країни повинно стикуватися 3 можливостями $\mathrm{i}$ напрямками розвитку регіонів та навпаки, розвиток регіонів повинен чітко інтегруватися в стратегію розвитку країни в цілому. Розвиток електронних комунікацій розпочався в країни давно, але усі суб'єкти управління мають різний рівень впровадження: начальна веб-присутність, взаємодія, транзакція.

Тому почати потрібно з аналізу того:

- яка головна мета - якість адміністративних послуг, зниження витрат за рахунок підвищення ефективності, електронна участь громадян у суспільному житті, формування довіри до держави, трансформація державного управління, розвиток території;

- що ми маємо на даний час: кількість та якість доступних електронних послуг; існуюча нормативна база; організаційна структура; людські ресурси; інфраструктура IКT; потенціал суспільства; потенціал бізнес структур; рівень довіри суспільства;

- які інструменти будуть використовуватися;

- які фактори будуть індикаторами досягнення цілі.

Висновки. Таким чином, для успішної трансформації електронного урядування потрібно мати чітко окреслені пріоритети розвитку міст і регіонів в контексті розвитку на рівні держави. В залежності від можливостей та проблем окремого міста чи регіону повинна бути розроблена стратегія розвитку та трансформації 3 конкретно окресленими пріоритетами та інструментами задля досягнення мети.

\section{Jimepamypa:}

1. Околёснова О. А. Электронное правительство как новый информационно-правовой механизм публичного управления // Вестник ТвГУ. Серия: Право. - 2017. - № 4. - С. 183 - 192.

2. Запорожець Т.В. Перспективні напрями запровадження механізмів інтелектуального управління в діяльності органів публічної влади // Вісник Національної академії державного управління при Президентові України. - 2020. - №2 (97). - С. 36-44.

3. United Nations (2020). UN E-government Survey 2020 [Електронний ресурс]. - Режим доступу: https://publicadministration.un.org/en/Research/UN-e-Government-Surveys 
4. World Justic Progect [Електронний ресурс]. - Режим доступу: https://worldjusticeproject.org/rule-of-law-index/country/2020/Ukraine

5. Портал відкритих даних. Наявність покриття населених пунктів України волоконнооптичнии мережами [Електронний ресурс]. https://data.gov.ua/dataset/788580dd-e3ae-45b4-a93b-f7f3e8a3f80d

6. Павлютенкова М. Ю. Электронное правительство vs цифровое правительство в контексте цифровой трансформации // Мониторинг общественного мнения : Экономические и социальные перемены. - 2019. - № 5. С. 120-135. https://doi.org/10.14515/monitoring.2019.5.07

7. Frach L., Fehrmann T., Pfannes P. (2017) Measuring Digital Government: How to Assess and Compare Digitalisation in Public Sector Organisations. In: Falk S., Römmele A., Silverman M. (eds) Digital Government. Springer, Cham. https://doi.org/10.1007/978-3-319-38795-6_2

\section{References:}

1. Okolyosnova, O. A. (2017). Elektronnoe pravitel'stvo kak novyj informacionno-pravovoj mekhanizm publichnogo upravleniya [E-government as a new information and legal mechanism of public administration] // Vestnik TvGU. Seriya: Pravo - Herald Of Tver State University. Series: Law, 4, 183 - 192 [in Russian].

2. Zaporozhec, T.V. (2020) Perspektivni napryami zaprovadzhennya mekhanizmiv intelektual'nogo upravlinnya $\mathrm{v}$ diyal'nosti organiv publichnoï vladi [Prospective directions of implementation of intellectual management mechanisms in the activities of public authorities]. Visnik Nacional'noï akademiï derzhavnogo upravlinnya pri Prezidentovi Ukraïni - Bulletin of the National Academy of public administration under the President of Ukraine, 2 (97), 36-44 [in Ukrainian].

3. United Nations (2020). UN E-government Survey 2020. Retrieved from https://publicadministration.un.org/en/Research/UN-e-Government-Surveys

4. World Justic Progect. Retrieved from https://worldjusticeproject.org/rule-of-lawindex/country/2020/Ukraine

5. Portal vidkritih danih. Nayavnist' pokrittya naselenih punktiv Ukraïni volokonno-optichnimi merezhami [Open data portal. Availability of coverage of Ukrainian localities with fiber-optic networks]. Retrieved from https://data.gov.ua/dataset/788580dd-e3ae-45b4-a93b-f7f3e8a3f80d

6. Pavlyutenkova, M. Y. (2019) Elektronnoe pravitel'stvo vs cifrovoe pravitel'stvo v kontekste cifrovoj transformacii [E-government vs digital government in the context of digital transformation]. Monitoring obshchestvennogo mneniya: Ekonomicheskie i social'nye peremeny - Monitoring public opinion: Economic and social changes, 5, 120-135. Retrieved from https://doi.org/10.14515/monitoring.2019.5.07.

7. Frach L., Fehrmann T., Pfannes P. (2017) Measuring Digital Government: How to Assess and Compare Digitalisation in Public Sector Organisations. In: Falk S., Römmele A., Silverman M. (eds) Digital Government. Springer, Cham. https://doi.org/10.1007/978-3-319-38795-6_2 